\title{
РЕЦЕНЗЇ̈
}

КАЛИНОВСЬКИЙ Б. В., доктор юридичних наук, професор, завідувач кафедри конституційного права та прав людини

(Національна академія внутрішніх справ)

DOI https://doi.org/10.32842/2078-3736/2020.6.2.2.32

\section{РЕЦЕНЗІЯ НА МОНОГРАФІЮ КОЛОДІЯ ОЛЕКСІЯ АНАТОЛІЙОВИЧА «КОНСТИТУЦЙНО-ПРАВОВИЙ СТАТУС УКРАЇНСЬКОГО НАРОДУ: ДОКТРИНА, РЕГЛАМЕНТАЦІЯ, ПОНЯТТЯ ТА ЕЛЕМЕНТИ»'}

Монографічна робота, що рецензується, присвячена досить актуальній із позиції як юридичної науки й сучасної конституціоналістики, так і практики конституційного будівництва та демократичної модернізації української державності проблемі - пізнанню доктрини, регламентації, поняття та елементів конституційно-правового статусу Українського народу. Адже прийняття Конституції України не лише засвідчило правове оформлення нових політичних, економічних і духовних реалій держави й суспільства, за яким Український народ та українська держава живуть уже понад 24 роки, і зумовило приєднання України до загальновизнаних демократичних цінностей конституційного рівня, фундаментальне й системоутворююче значення з-поміж яких посідає доктрина конституціоналізму, але й поставило на порядок денний необхідність комплексного політичного, економічного, духовного та правового забезпечення конституційно-правового статусу Українського народу, корінних народів і національних меншин.

Саме тому сучасний етап розвитку юридичної науки характеризується посиленням уваги до доктринальних проблем конституційно-правових статусів вищезазначених суб'єктів. Колосальний інтерес до проблеми конституційно-правового статусу Українського народу зумовлений багатьма факторами, зокрема й завданнями та потребами концептуального забезпечення його визнання, функціонування і розвитку, що своєю чергою детермінує необхідність інтенсивного розвитку та якісного вдосконалення законодавства, яке його регламентує. Особливий інтерес проблема конституційно-правового статусу Українського народу викликає з позиції реалізації Конституції і конституційного законодавства, формування конституціоналізму та проведення конституційної реформи в Україні. Безумовно, у чинній Конституції України вже відображені доктринальні засади сучасного конституційно-правового статусу Українського народу, закладені поняття, елементи, сутність, правосуб'єктність, принципи, повноваження, гарантії, які забезпечують його реалізацію та знаходять своє продовження в законодавстві України. 3 іншого боку, правореалізаційна практика свідчить про те, що є життєва потреба в підвищенні якості та кількісному збільшенні чинників, які гарантують реалізацію конституційно-правового статусу Українського народу.

На жаль, вітчизняна конституційно-правова наука досі не виробила чітку позицію щодо багатьох проблем сутності, змісту й розвитку конституційно-правового статусу Українського народу, насамперед стосовно забезпечення реалізації Конституції України в зазначеній сфері, конституційних повноважень Українського народу, організації та реалізації

1 Колодій О.А. Конституційно-правовий статус Українського народу: доктрина, регламентація, поняття та елементи : монографія. Київ : Видавництво «Ліра-К», 2020. 452 с.

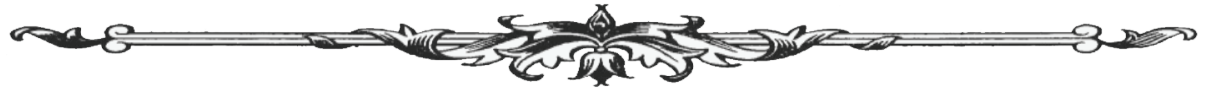


інших елементів його статусу, конституційно-правової відповідальності органів і посадових осіб публічної влади за якісне забезпечення його повноцінного втілення.

Водночас $є$ всі підстави стверджувати, що без глибокого теоретичного наукового дослідження та всебічного вивчення проблем, пов'язаних із конституційно-правовим статусом Українського народу, неможливо вирішити актуальні практичні питання реформування українського суспільства й держави. Необхідний багатоаспектний аналіз конституційно-правового статусу Українського народу, який дасть змогу підійти до вирішення багатьох практичних питань конституційного будівництва України, а саме до формування національного громадянського суспільства й демократичної, соціальної та правової держави, євроінтеграційної та північноатлантичної політики тощо. Тобто йдеться про необхідність вироблення нових підходів у науці конституційного права України до розуміння й реалізації конституційно-правового статусу Українського народу.

Одним із таких пошуків відповідей на наявні проблеми в конституційному праві $\epsilon$ саме рецензована монографія. Ї̈̈ автор застосував комплексний підхід, який дав можливість зробити системні висновки під час визначення результатів та обгрунтування низки нових положень, що мають важливе значення для конституційно-правової науки й практики.

Монографічна робота «Конституційно-правовий статус Українського народу: доктрина, регламентація, поняття та елементи» охоплює широке коло актуальних теоретичних і практичних проблем конституційного права України. Так, значний інтерес для тих, хто досліджує, цікавиться проблемами сучасного конституційного права України та викладає відповідні дисципліни, представляють питання щодо поняття й елементів, сутності, правосуб'єктності, принципів, установчих, організаційно-легітимаційних, правотворчих, судових, контрольно-наглядових, майнових повноважень Українського народу. Також автором глибоко проаналізовано загальносоціальні та спеціально-юридичні гарантії конституційно-правового статусу Українського народу. У роботі досліджено стан наукових пошуків і регламентацію правового статусу народів загалом.

Варто зазначити, що в рецензованій монографії органічно поєднуються теорія, нормативно-правові акти та вітчизняна практика. Вивчення актуальних проблем конституційноправового статусу Українського народу має колосальне й системоутворююче значення для правотворчості, правореалізації, правоохорони, науково-дослідної сфери, навчального процесу, правовиховної роботи.

На основі цього можна зробити висновок, що монографія Колодія Олексія Анатолійовича «Конституційно-правовий статус Українського народу: доктрина, регламентація, поняття та елементи» $€$ істотним внеском у розвиток вітчизняної науки та практики конституційного права.

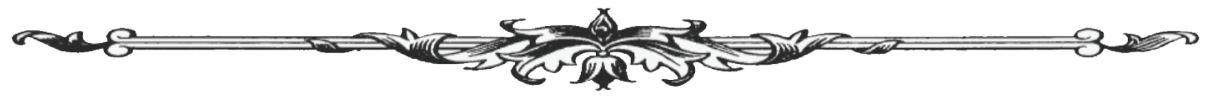

